\title{
Choroidal and Ciliary Body Melanoma pT2 TNM Finding v8
}

National Cancer Institute

\section{Source}

National Cancer Institute. Choroidal and Ciliary Body Melanoma pT2 TNM Finding V8. NCI

Thesaurus. Code C140636.

Choroidal and ciliary body melanoma, tumor size category 2. (from AJCC 8th Ed.) 